\title{
THE ESTABLISHMENT OF THE EARLY SCHOLARSHIP OF PROFESSIONAL AND TECHNICAL SURVEYING EDUCATION IN SOUTH AFRICA FOR THE PERIOD 1657 to 1929
}

\author{
Koos Landman ${ }^{1}$; Mulemwa Akombelwa ${ }^{2}$; Angus Forbes ${ }^{3}$ \\ ${ }^{1}$ Mangosuthu University of Technology, \\ 23. University of KwaZulu-Natal
}

\section{DOI: http://dx.doi.org/10.4314/sajg.v6il.1}

\begin{abstract}
Historical Research deals with the meaning of events, and it tries to make sense of an everflowing stream of events and continuing changes in human life and its institutions. Surveying activities in South Africa, sometimes by people with no survey-specific education, started in 1657.

Early in the 19th century, disputes arose regarding the positions of boundary beacons and the incorrect diagrams representing them. In 1834, the Cape Colony government decreed that land surveyors should only be allowed to practise after completing a qualifying examination set by the Surveyor-General. Early land surveyors were expected to be competent in cadastral, engineering, topographical and mine surveying, and cartography.
\end{abstract}

This paper will focus on the time period before the existing familiar Professional Degrees and National Diplomas were offered by Universities in South Africa. It will highlight the remarkable achievements of the early surveyors, some of whom were self-taught, and their mentors. It will investigate the first formal learning that surveyors had to undergo to acquire the competencies needed to practise as surveyors.

Keywords: Universities, technikons, colleges, surveying, profession

\section{Introduction}

"Education is a fundamental attribute of the professional surveyor. It is the foundation upon which the surveyor builds his/ her skills and his/ her experience. It is through education that the surveying profession adapts to changing conditions and changing attitudes within society" (Fisher, 1985).

Professional education must address technical questions and must include a solid scientific and mathematical grounding, questions of ethics and values and the methodologies of decision making 
when values are in conflict. University tuition as opposed to other kinds of education is the training of the mind in as broad a sense as possible (Menzies, 1949; Weir, 1985).

To estimate the future of any profession it is necessary to look at its past. The survey profession in South Africa has performed a most vital technological service in the unlocking of a continent thus far indifferent to technology (Mallows, 1967).

\subsection{The education of surveyors in ancient times}

Surveying is known to be the oldest profession in the world having traced its roots back to great civilizations of ancient times, such as the Babylonians, Greeks, Egyptians, and the Chaldeans where surveyors were noblemen (Ferris State University, 2015). Historians vary in their opinions on the origin of surveying. Diodorus, Herodotus and Strabo, attribute the invention of it to the Egyptians. According to Josephus, however, the arts and sciences of Egypt were derived from the patriarch Abraham, who conveyed them into that country, from Ur of the Chaldees (Nesbit, 1820).

\subsection{The education of Surveyors in South Africa in the $17^{\text {th }}$ to $18^{\text {th }}$ centuries}

The first surveyors in South Africa had no formal survey education. However, the first "lantmeter in dienst van den Compagnie", Pieter Potter, a midshipman from Amsterdam, arrived at the Cape in August 1655, attached to the crew of the Nieuw Rotterdam (Historical Society of Cape Town, 2006). There can be little doubt that the survey profession has played a pivotal role in the development of South Africa from the time when Potter was appointed the first sworn land surveyor by the Dutch East India Company (Stern, 1978). He demarcated boundaries of land parcels, placed beacons, provided numerical data for diagrams for registration and prepared maps (Committee for the History of Surveying and Land Tenure in South Africa, 1983).

It is noted in the South African Survey Journal (April 1976) that the first diagram representing a portion of land was that drawn by Potter in 1657. However, van der Sterr (1918) states that the boundaries demarcated on the first diagrams were probably made by Caspar van Weede van Stoutenberg, who was considered to be a good draughtsman. It is also documented that an accurate topographical map of the Cape coast was made by Surveyor Potter in July 1657 and it can therefore be argued that he was also one of the early cartographers.

Potter was also the original South African engineering surveyor, by laying out the Company's Gardens and taking levels across the Cape Flats for the design of a proposed canal which would have eliminated the hazardous voyage round the Cape of Storms (Hurley, 1989). This job of measuring the distance between the two bays, Table Bay to False Bay, was quite a project and would have been a huge undertaking even three centuries later (West, 1971).

Potter was not a land surveyor by training, but he was literate, numerate and artistic, and had gained some experience at chart making. Potter is recognised as the progenitor of land (cadastral) surveying as a profession and his methods of recording rights in land are still in use in South Africa 
(Fisher, 1984). He is known to have spent six years in the Cape and his origins and eventual fate remain uncertain (Fisher, 1982).

Potter's immediate successors to the office of land surveyor were also selected for their general abilities rather than for a special knowledge of land measurement (Fisher, 1982). Land surveyors who were Potter's successors (1661 - 1739) included Hendrick Lacus - listed as a cadet in the 1660 muster roll but destined to be Potter's first successor as land surveyor. During their joint survey of Saldanha Bay these two surveyors contrived to name two inlets after themselves: Lacus Bay (now Noordbaai) and Potter Bay (now Hoedjiesbaai). Neither name has survived (Fisher, 1982 \& 1984).

Lacus was superseded by Joan Wittebol, who in turn was followed by Johannes Mulder - a shopkeeper with surveying knowledge - sent out from Holland and served as "Landmeter" from 1685 to 1694 (Menzies, 1949), Heinrich Bernhard Oldenland, Douw Gerbrandets Steyn, Kaje Jesse Slotsboo and Evert Walrave Cochius. (Fisher, 1984). During the period from 1740 to 1806, a further ten land surveyors have been identified but little is known of their activities, other than the grant diagrams for which they were responsible (Hurly, 1983).

\subsection{The contribution to survey education by South African ethnicities}

The early Dutch and British settlers in South Africa, and later the migrants into the interior, met with indigenous cultures who practised indigenous forms of land ownership. These forms of ownership were based on communal, and not individual rights in land.

When van Riebeeck first settled at Table Bay nothing whatsoever was known by the settlers of the country lying beyond, and little information could be gathered from the Hottentot (Khoi Khoi) tribes. Then the settlement gradually spread, and with it the people developed that wonderful "veld sense" by which they carried fairly accurate pictures of the country in their minds, and could express the positions of geographical features in terms of days' journeys or hours on horseback; useful data in a young and unmapped country (Jack, 1929). Such a system had no technical reinforcement.

The early settlers and the indigenous Khoi Khoi had a cordial but tense co-existence, although conflicts did occur. Boundaries of farms were sometimes established by riding out in all directions from a central point. Such arbitrary annexations resulted in confrontation between the Dutch and the Khoikhoi, and later also the San (Bushman) (Guelke, 1984).

The complexity and variety of African communal tenure, and the measure of western ignorance about them, have been well emphasised, but a notion of land ownership was not lacking amongst black Southern Africans, even though they had no system of survey and recording (Davenport and Hunt, 1974). Due to the eventual situation, black work-seekers had to look for work under a migrant labour system, giving them only certain inferior rights in white areas. This resulted in a lack of technical education for black South Africans. However, communal land tenure systems form an 
integral part of any survey syllabus at universities today, which is a legacy of early land ownership under African communal tenure as experience by the early European settlers.

\subsection{The influence of early astronomers on survey education in South Africa}

In the year 1751, the Abbé Nicolas-Louis de Lacaille, arrived in South Africa and set about the measurement of a meridian arc in the Southern Hemisphere where no arc had previously been measured $\mathrm{He}$ was responsible in part for initiating what was to become the basis of the South African trigonometrical system (Menzies, 1967; Simpson, 1989). Lacaille was essentially selftaught in mathematics and geodesy (Smith, 2001). However, it is claimed by Glass (2012) that he trained at the Paris Observatory. In 1739 he was appointed to the Chair of Mathematics at College Mazarin des Quatre-Nations in Paris (NGI, 2013).

Some ninety years later, Sir Thomas Maclear, Her Britannic Majesty's Astronomer at the Cape, performed a verificatory meridian arc upon the recommendation of Sir George Everest (Simpson, 1989). Having completed the verification of LaCaille's meridian arc, Maclear went on to extend his triangulation northwards to a point near Kamieskroon in Namaqualand and eastwards towards Cape Agulhas. The points which Maclear surveyed in these extensions would eventually become the foundation of all subsequent geodetic operations and survey work in South Africa leading one to suggest that Maclear can be considered to be the father of the highly-respected survey system which we have in South Africa (NGI, 2013).

Maclear was destined to be educated as an Anglican cleric, but in 1814 he went to London to study medicine at Guy's and St Thomas's Hospitals and was admitted as a Member of the Royal College of Surgeons of London (MRCS). Maclear's increasing interest in astronomy led him to study mathematics in his spare time and make observations with a small telescope. Encouraged by Captain (later Admiral) Smyth and others he became active in astronomical circles. He built his own observatory at Biggleswade and equipped it with a small transit instrument and a telescope borrowed from the Royal Astronomical Society. His observations and calculations was of such quality that he was elected a Fellow of the Royal Astronomical Society in 1828, a Fellow of the Royal Society of London in December 1831, and a member of the Academy of Sciences, Palermo, in 1835 (Plug, 2017).

Sir David Gill had persuaded the British authorities in 1879 that a geodetic triangulation was necessary for all future surveying and mapping of the country. He also considered such a survey as the beginning of a measurement along the 30th Arc of Meridian which would not only act as a backbone for all surveying and mapping in Africa, but could also be used for precise geodetic measurements to calculate the figure of the earth (Liebenberg, 2003).

In 1858 he attended the Junior Mathematical Class at Marischal College, followed by attending the Classes of Senior Mathematics and Natural Philosophy at Marischal College in 1859-60. David 
Thomson, at the age of twenty-eight, was appointed "Regent and Professor of Natural Philosophy in the University and King's College, Aberdeen." In the biography of David Thomson, we read that Astronomy, too, had great attractions for him, and he spent many hours in the old square tower, which used to be called by the name of Cromwell, in the Observatory which he founded there. It was here that the present Astronomer Royal at the Cape, Dr. Gill, was inspired by Professor Thomson with his well-known enthusiasm for the science of the heavenly bodies (Forbes, 1916).

The names of the two astronomers, Maclear and Gill, will forever be synonymous with triangulation in South Africa (Rousseau and Wonnacott, 1982). The national triangulation network which we have come to take for granted in South Africa is based primarily on the work of Sir David Gill who initiated the survey just over one hundred years ago (Wonnacott, 1985).

These astronomers, having contributed immensely to the present survey system in South Africa, have, by virtue of their work, made crucial contributions to survey syllabi in South African universities.

\subsection{Education of British surveyors involved in the Anglo-Boer War}

In the Anglo-Boer War (1899 - 1902), good maps were not nearly so necessary to the mobile scattered Boer forces as to the British leaders, who were much handicapped by this lack of good maps (Jack, 1929). Before, during and after the War the British War Office launched several commendable efforts to obtain maps of the country. Most of these maps were compilation maps which were compiled by the Field Intelligence Department of the War Office from whatever survey, cartographic and topographical material were available. Only a small percentage of the maps issued were actual survey maps based on local topographical surveys executed by Royal Engineers. (Liebenberg, 2001).

Two survey sections were despatched to South Africa during the war, and provision was made for three mapping sections. No 1 Survey Section was under the command of Captain HM Jackson who was later promoted to Major and did valuable work in the Transvaal until the cessation of hostilities when he became Surveyor-General of the Transvaal Colony. No 2 Survey Section under Captain PH du P Casgrain, was based in Cape Town, whereas a mapping section was based in Bloemfontein under the supervision of Major AHF Duncan. Major SCN Grant, who supervised the production of topographical maps at the War Office, became Director-General of the Ordnance Survey in 1908 (Liebenberg, 2003).

By the end of the Anglo-Boer War Sir David Gill (see 1.4 above) continued his negotiations with the British Government for the extension of the Geodetic Survey to the two new colonies, and from 1902 and 1906 a team of military surveyors completed the geodetic survey of the Transvaal and Orange River Colonies (Liebenberg, 2003).

With the cessation of hostilities, Britain realised that if it wanted to sustain its imperial influence in Southern Africa, it would have to make provision for the topographic mapping of the colonies. 
As a result, survey sections were despatched to South Africa to undertake accurate topographic mapping (Liebenberg, 2003). All the British surveyors, before and after the Anglo-Boer war, were despatched from and therefore educated in Britain.

The emphasis on science in the early curriculum was probably due to the influence of Dr W.C. Van der Sterr, the first Director of Trigonometrical Surveys who played a large role in the establishment of the first surveying degree at Cape Town, and it bears a close resemblance to curricula which were current in Europe at the time (Jones, 1982).

\section{The early education of surveyors in South Africa}

Early in the 19th century, disputes arose regarding the positions of boundary beacons and the incorrect diagrams representing them (Watermeyer, 1917). In 1834, the Cape Colony government decreed that land surveyors should only be allowed to practise after completing a qualifying examination set by the Surveyor- General (Van der Spuy, 1974). In that year, in the Cape, examinations were introduced for persons who wished to qualify for the right to practise as land surveyors and similar provisions were introduced in the other territories which eventually made up the Republic of South Africa. At the time of Union control of land surveyors' examinations was vested in the University Council in the Cape and in Boards of Public Examiners in the Transvaal and Orange Free State. (Jones, 1982). This was specifically an assessment of competence and not formal education.

Formal education of surveyors in South Africa dates back to 1878 at the Diocesan College, Cape Town, and for the period 1878 to 1886,31 students passed the course. No records exist for the period 1887 to 1889 , but from 1890 to 1899 there were a further 23 passes. An early record from St. Andrews College in Grahamstown is a photograph, taken at around 1882 showing five survey students. It is possible that there may have been some students prior to 1882 , and there is evidence that mathematics was taught in 1878. In 1904 St. Andrews College became Rhodes University College and the survey class of 34 was the largest so far in South Africa. The survey course was a one-year Diploma Course, although 10 students decided to do the course over a period of two years. From 1906 the course became a two-year course. The Rhodes University Calendars of 1952 - 1954 give details of a 3-year course. In 1904 St. Andrews College became Rhodes University College and the survey class of 34 was the largest so far in South Africa. The survey course was a one-year Diploma Course, although 10 students decided to do the course over a period of two years. From 1906 the course became a two-year course. The Rhodes University Calendars of 1952 - 1954 give details of a 3-year course. The last students passed the Diploma Course at Rhodes in 1958, after being offered for 55 years. Together with St. Andrews College the period spanned 79 years (Landman et al, 2013) 
Stellenbosch College was founded in 1881. In 1882 Stellenbosch College started offering classes in surveying, but apparently, this did not result in a recognised qualification is surveying. In 1887 Stellenbosch College became Victoria College and a two-year diploma course was commenced in 1893. Victoria College became Stellenbosch University in 1918, but no further information on this course after 1920 could be found (Landman et al, 2013).

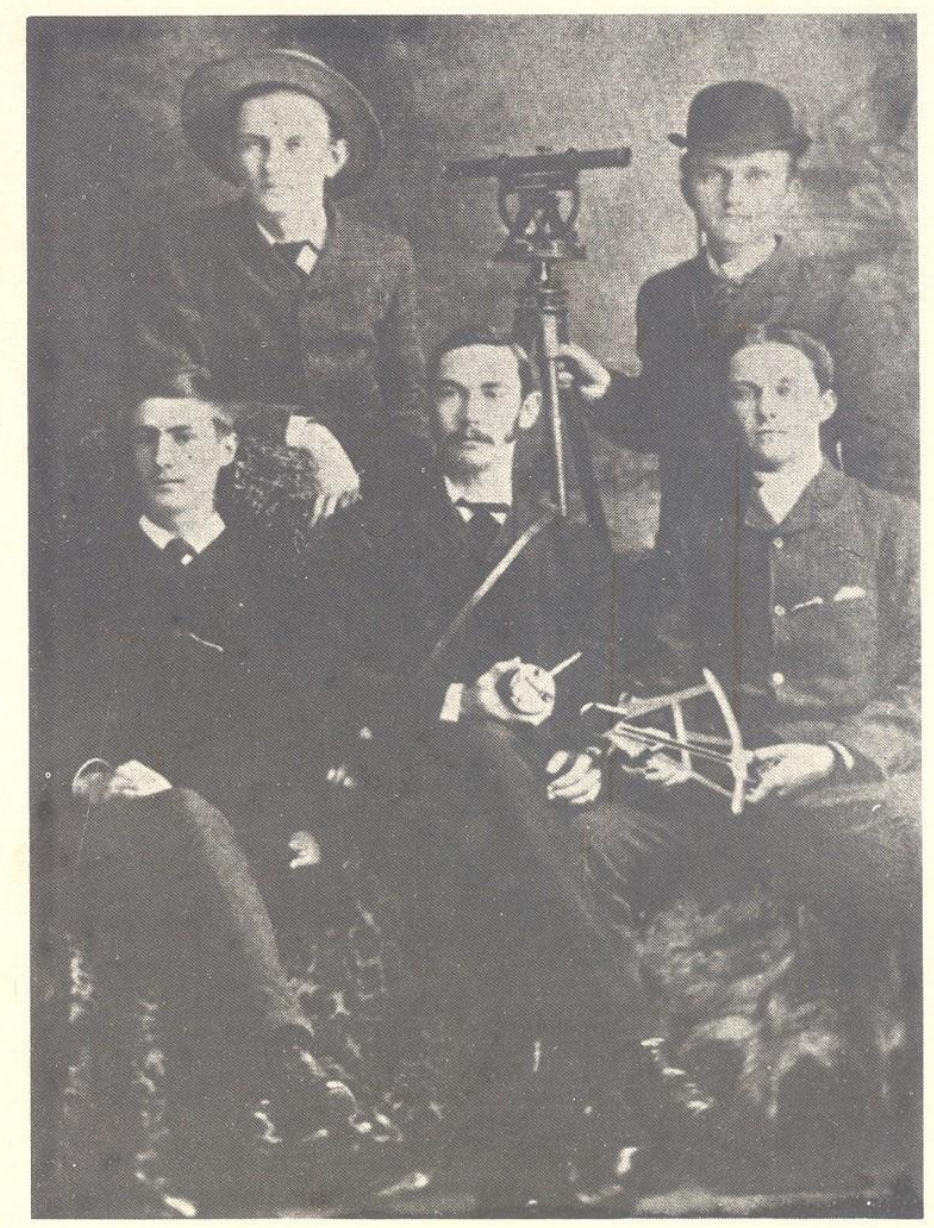

Figure 1. Dr. R.F. Currey's book on St. Andrew's College, cited by Brereton (1973): An early record from St. Andrews College in Grahamstown is a photograph, taken at around 1882 showing five survey students. South African Survey Journal, Vol.XIV, Part 3, pp.12-16

In 1916 a Joint Committee for Professional Examinations was established which was entrusted with responsibility for land surveyors' examinations among others. Admission to practice was by means of a pass in the theoretical and practical examinations set by the Joint Committee after a period of articles under the supervision of a land surveyor. Initially there was no institution where 
prospective candidates could obtain tuition to prepare themselves for the theoretical examinations and failure rates were high. In an attempt to remedy the situation Rhodes University College introduced a series of lectures aimed at preparing candidates for the theoretical examinations but the high failure rate continued (Jones, 1982). A reason for the high failure rate could partly be due to the Law Examinations required for professional registration.

Ever since the days of Jan van Riebeeck and Potter of the mid-seventeenth century, the question of land surveyors' qualifications had received attention, but it was not until 1928, as a result of the efforts of Dr W.C. van der Sterr in consultation with Professor Alfred Snape, head of the Department of Civil Engineering at the University of Cape Town, that a four-year degree course in land surveying was inaugurated (Thomas, 1982). The first 4-year BSc classes commenced at the Universities of Cape Town and the Witwatersrand in 1929 (Menzies, 1967). When the first surveying degree was introduced in 1929 the initial curriculum placed great emphasis on measurement science, mathematics and physics in addition to cadastral oriented courses and this emphasis was taken up and continued in the subsequent degree courses until the early 21 st century when significant changes were made to accommodate new technology and its impact on the work of the classical land surveyor (Jones, 1982).

\section{Discussion and Conclusion}

In this article, the early education of practitioners in the South African survey profession has been emphasised. While the initial surveyors in the early Cape Colony had little or no formal education, this was not the case of the early astronomers who laid the foundation for the present survey system in South Africa, and therefore their contribution still forms a major part of survey syllabi at South African universities. The curriculum of the first surveying degree included measurement science, mathematics, physics and cadastral oriented courses, and it can therefore be argued that the early survey practitioners all contributed indirectly to the development of these study areas.

The early formal assessment of the competencies of surveyors in South Africa started in 1834 after disputes arose regarding the positions of boundary beacons, and land surveyors were required to pass a qualifying examination before they could practise. Formal education started in 1878 and in the years that followed a range of qualifications were offered by several institutions. Professional Examinations required for the right to practice started in 1916.

Throughout the time period covered in this article, the question of land surveyors' qualifications had received attention. This resulted in a 4-year BSc Degree starting at the Universities of Cape Town and the Witwatersrand in 1929.

It has been demonstrated in the preceding sections that all surveying has several functions which can only be performed by someone with advanced knowledge and qualifications and in some 
circumstances, supplemented by considerable experience. These can be defined as professional functions. As part of these functions there are activities of a more routine nature, which can be performed by trained aides with less advanced knowledge and qualifications. These are the technician functions and in certain circumstances, considerable experience is necessary for the efficient performance of them. The fact that these two are complementary to each other for the efficient functioning of the survey discipline is emphasised. Both are essential in any big survey organisation (Marsh, 1967).

There is therefore a continuing need for the education of surveyors at professional level and technical level. This, of course, has long been recognised and education at these levels is being provided today by Universities and Universities of Technology.

\section{REFERENCES}

Brereton, VCHR 1973 'The Early Education of Land Surveyors', South African Survey Journal, Vol.XIV, Part 3, pp.12-16

Committee for the History of Surveying and Land Tenure in South Africa, first symposium on the history of surveying and land tenure in the Cape: 1652-1812. University of Stellenbosch, July 1983.

Davenport, TRH and Hunt KS (Eds) 1974, The Right to the Land, David Philip Publisher Cape Town. Ferris State University, What is Surveying Engineering, viewed August 2015, www.ferris.edu/HTMLS/colleges/cot/surveying/AboutSURE/aboutsure.htm

Fisher, RC 1982, 'Pieter Potter of Amsterdam. The first South African land surveyor', proceedings, Conference of Southern African Surveyors, Johannesburg.

Fisher, RC 1984, 'Land Surveyors and Land Tenure at the Cape 1657 - 1812' in CGC Martin and KJ Friedlaender (eds.) History of Surveying and Land Tenure in South Africa, Volume One: Surveying and Land Tenure in the Cape 1652 - 1812, Department of Surveying, University of Cape Town, South Africa. Fisher, RC 1985, 'Education for the Surveying Profession in South Africa, a critical review', proceedings, Conference of Southern African Surveyors, Durban.

Forbes, G 1916, David Gill Man an Astronomer, John Murray, London.

Guelke, L 1984, 'Land Tenure and Settlement at the Cape, 1652-1812' in CGC Martin and KJ Friedlaender (eds.) History of Surveying and Land Tenure in South Africa, Volume One: Surveying and Land Tenure in the Cape 1652 - 1812, Department of Surveying, University of Cape Town, South Africa.

Historical Society of Cape Town 2006, 'Pieter Potter - South Africa's first surveyor', Cabo, Volume 9, Issue 1 , p. $11-12$.

Hurly, RF 1983, 'Josias Eduard de Villiers - Surveyor and Astronomer', South African Survey Journal, Vol.XIX, Part 2, (No.113), pp. 24-28.

Jack, EM 1929, 'The Ordnance Survey of Great Britain', South African Survey Journal, Vol.III, Part V, (No.21).

Jones, BM 1982,' A Broadly-Based Profession - Education for Change', proceedings, Conference of Southern African Surveyors, Johannesburg.

Landman, JC et al 2013, 'A Historical Review of The Development of Learning Programmes in Higher Education in South Africa' proceedings, SA Surveying and Geomatics Indaba, Ekhurhuleni.

Liebenberg, E 2001, 'The 1:500 000 “Irrigation Map” of South Africa, 1935-1937' proceedings, Conference of Southern African Surveyors, Johannesburg. 
Liebenberg, E 2003, 'The Cartographic Legacy of the Anglo-Boer War, 1899-1902' proceedings, 21 st International Cartographic Conference, Durban.

Mallows, EWN 1967, 'Education and Status of Surveyors', proceedings, Conference of Southern African Surveyors, Johannesburg.

Marsh, FW 1967, 'Education and Status of Surveyors', proceedings, Conference of Southern African Surveyors, Johannesburg.

Menzies, GH 1949, 'The History, Purpose and Progress of Land Surveying (With Special Reference to South Africa)' South African Survey Journal, Vol VII, Part IV, (No. 45), pp. 248-258.

Menzies, GH 1967, 'Education of Surveyors', proceedings, Conference of Southern African Surveyors, Johannesburg.

Menzies, GH 1967, 'The Contribution of the Cape to Geodesy in South Africa', proceedings, Conference of Southern African Surveyors, Johannesburg.

Nesbit, A 1820, A complete Treatise on Practical Land-Surveying, 2nd edition, Longman, Hurst, Rees, Orme, and Brown, Paternoster-Row, London: and Wilson and Sons, York.

NGI, 2013, History of Geodetic Surveying in SA,2013, National Geo-Spatial Information, viewed December 2015, http://www.ngi.gov.za/index.php/technical-information/geodesy-and-gps/history-of-geodeticsurveying-in-sa

Plug, C 2017, Maclear, Sir Thomas, S2A3 Biographical Database of Southern African Science, viewed March 2017, http://www.s2a3.org.za/bio/Biograph_final.php?serial=1791

Rousseau, DPM and Wonnacott, RT 1982, 'State of the re-triangulation of RSA, incorporating satellite doppler observations', proceedings, Conference of Southern African Surveyors, Johannesburg.

Simpson, K 1989,'a History of the South African Trigonometrical system', South African Journal of Surveying and Mapping, Vol.20, Part 3 (No.120), pp. 109-119.

Simpson, K 1989, Control Point Surveying, 1st edition, ML Sultan Technikon, Durban.

Smith, JR 2001, 'Lacaille- French Astronomer and Geodesist' proceedings, Conference of Southern African Surveyors, Cape Town.

South African Survey Journal 1976, News and Opinion, No. 91, Vol. XV, Part 4.

Stern, E 1978, 'The Land Surveyor and Multi-Disciplinary Practice' proceedings, Conference of Southern African Surveyors, Cape Town.

Thomas, PW 1982,' The Topographical 1:50 000 Map Series of South Africa', South African Journal of Photogrammetry, Remote Sensing and Cartography, Vol.13, Part 2, pp.77-88.

Van der Spuy, E 1974, 'Urban Surveying in the Republic of South Africa', proceedings, Conference of Southern African Surveyors, Salisbury, Rhodesia.

Van der Sterr, WC 1918,' Security of Title and How to Obtain It', Journal of the Institute of Land Surveyors of the Transvaal, Vol.III, No. 11, pp 522 - 529.

Watermeyer, FS 1917 'Another Criticism of the Survey System in Vogue in the Union of South Africa, with an Appeal for an Immediate Drastic Alteration' Journal of the Institute of Land Surveyors of the Transvaal, Vol.III, No. 10, pp 444 - 451.

West, ID 1971, 'Pieter Potter- The First Surveyor of the Cape', South African Survey Journal, Vol.XIII, Part 2, (No. 77) pp. 22-27.

Wonnacott, R 1985, 'Modern Geodetic Surveying and Distortions in the National Network', proceedings, Conference of Southern African Surveyors, Durban. 